\title{
DOE/MC/30360-95/C0425
}

Conf-9411149--12

\section{ACOUSTICALLY ENHANCED REMEDIATION OF CONTAMINATED SOIL AND GROUND WATER}

\section{Authors:}

Joe L. Iovenitti

Timothy M. Rynne

James W. Spencer, Jr.

Contractor:

Weiss Associates

5500 Shellmound Street

RECEIVED

Emeryville, CA 94608-2411

\section{Contract Number:}

DE-AR21-94MC30360

\section{Conference Title:}

Proceedings of Opportunity '95 - Environmental Technology Through Small Business

\section{Conference Location:}

Morgantown, West Virginia

\section{Conference Dates:}

November 16 - 17, 1994

\section{Conference Sponsor:}

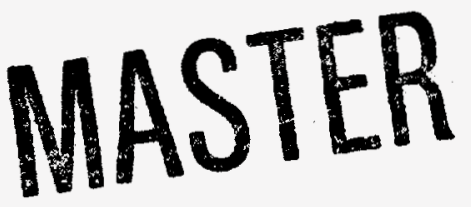

U.S. Department of Energy - Morgantown Energy Technology Center 


\section{DISCLAIMER}

This report was prepared as an account of work sponsored by an agency of the United States Government. Neither the United States Government nor any agency thereof, nor any of their employees, makes any warranty, express or implied, or assumes any legal liability or responsibility for the accuracy, completeness, or usefulness of any information, apparatus, product, or process disclosed, or represents that its use would not infringe privately owned rights. Reference herein to any specific commercial product, process, or service by trade name, trademark, manufacturer, or otherwise does not necessarily constitute or imply its endorsement, recommendation, or favoring by the United States Government or any agency thereof. The views and opinions of authors expressed herein do not necessarily state or reflect those of the United States Government or any agency thereof.

This report has been reproduced directly from the best available copy.

Available to DOE and DOE contractors from the Office of Scientific and Technical Information, 175 Oak Ridge Turnpike, Oak Ridge, TN 37831; prices available at (615) 576-8401.

Available to the public from the National Technical Information Service, U.S. Department of Commerce, 5285 Port Royal Road, Springfield, VA 22161; phone orders accepted at (703) 487-4650. 


\section{DISCLAIMER}

Portions of this document may be illegible in electronic image products. Images are produced from the best available original document. 


\section{CONTRACT INFORMATION}

Contract Number

Contractor

Contractor Project Manager

Principal Investigators

METC Project Manager

Period of Performance

Schedule and Milestones
DE-AR21-94MC30360

Weiss Associates

5500 Shellmound Street

Emeryville, CA 94608-2411

(510) 450-6000

Joe L. Iovenitti

Joe L. Iovenitti

Timothy M. Rynne

James W. Spencer, Jr.

Richard McQuisten

July 21,1994 to July 20, 1995

FY94/FY95 Program Schedule

$\begin{array}{llllllllllllll}\text { A } & \text { S } & \text { O } & \text { N } & \text { D } & \text { J } & \text { F } & \text { M } & \text { A } & \text { M } & \text { J } & \text { J } & \text { A }\end{array}$

Literature Review

Test Plan

Fabricate Equipment

Laboratory Tests

Data Analysis

Topical Report

NEPA Information

\section{OBJECTIVES}

This program systematically evaluates the use of acoustic excitation fields (AEFs) to increase fluid and contaminant extraction rates from a wide range of unconsolidated soils. Successful completion of this program will result in a commercially-viable, advanced in-situ 
remediation technology that will significantly reduce clean-up times and costs. This technology should have wide applicability since it is envisioned to augment existing remediation technologies, such as traditional pump and treat and soil vapor extraction, not replace them.

The overall program has three phases.

- Phase I - Laboratory Scale Parametric Investigation

- Phase II - Technology Scaling Study

- Phase III - Field Demonstration

Phase I of the program, corresponding to this period of performance, has as its primary objectives to provide a laboratory-scale proof of concept, and to fully characterize the effects of AEFs on fluid and contaminant extraction rates in a wide variety of soil types. The laboratory measurements of the soil transport properties and process parameters will be used in a computer model of the enhanced remediation process. A Technology Merit and Trade Study will complete Phase I.

\section{BACKGROUND INFORMATION}

This section provides a brief overview of previous related studies on the effects of an acoustic excitation field (AEF) on fluid flow in porous media. It should be noted here that a wide variety of acoustical sources operating between seismic and ultrasonic frequencies, including standard mechanical oscillators, electromechanical flextensional transducers, compressed air driven oscillator systems, combustion and detonation wave driven acoustic generators, and other advanced technologies, are potentially applicable to acoustically enhanced remediaton.

\section{Review of Previous Related Studies}

There have been numerous studies, e.g., Duhon (1964), Beresnev and Johnson (1994), and Reddi and Challa (1994), that suggest the potential for acoustically enhanced remediation of contaminated soils and ground water. While a majority of these studies were directed toward developing techniques for enhanced oil recovery, there recently has been a realization that similar approaches may be useful for environmental remediation, e.g., Weiss Associates (1993) and Reddi and Challa (1994).

Many of the studies on the application of sonic energy to improve oil production were performed in the former Soviet Union. Beresnev and Johnson (1994) present a comprehensive review of both laboratory and field studies which suggest that the application of acoustic energy can increase the rate of oil production from subsurface reservoirs. Table 1 (next page), modified after Beresnev and Johnson, is a compilation of data from laboratory studies in the United States and the former Soviet Union.

The reported results from field studies are even more intriguing. While the field studies are in many cases poorly-controlled, they suggest that weak elastic waves from regional earthquakes or Vibroseis ${ }^{\text {TM}}$-type sources, with strain amplitudes below $10^{-7}$, can increase oil production from reservoirs as deep as 4,000 feet (1,200 meters). The effects appear to be most favorable when the reservoir is nearly depleted and the produced fluids have a water-cut over 90 percent. The duration of the increased oil production varied from 10 days to 147 days for acoustic excitation on the order of a few minutes (earthquakes) to a month (industrial vibratory sources). Weiss Associates (1993) conducted preliminary experiments to evaluate how low- frequency acoustic excitation affects the permeability of sand. Their experiments were conducted 
Table 1. Summary of Laboratory Studies on Effects of Acoustic Excitation on Permeability of Porous Media (Modified after Beresnev and Johnson, 1994)

\begin{tabular}{|c|c|c|c|c|c|c|}
\hline $\begin{array}{l}\text { Case } \\
\text { History } \\
\text { No. }\end{array}$ & Reference & $\begin{array}{l}\text { Observed Effect Caused by } \\
\text { Sound Ultrasound }\end{array}$ & $\begin{array}{l}\text { Frequency } \\
\text { Range }\end{array}$ & Sonic Field Intensity & $\begin{array}{l}\text { Duration } \\
\text { of } \\
\text { Excitation }\end{array}$ & $\begin{array}{l}\text { Duration of the } \\
\text { Effect After End } \\
\text { of Excitation }\end{array}$ \\
\hline $\mathrm{T}$ & $\begin{array}{l}\text { Duhon } \\
\text { (1964) }\end{array}$ & $\begin{array}{l}\text { Increased oil recovery during } \\
\text { water flood; reduction of water/oil } \\
\text { permeability ratio; increase of } \\
\text { flow rate into injection well }\end{array}$ & $\begin{array}{l}1-5.5 \\
\mathrm{MHz}\end{array}$ & $\begin{array}{l}50 W \text { (power of } \\
\text { transducer) }\end{array}$ & $6-9 h$ & NA \\
\hline 2 & $\begin{array}{l}\text { Nosov } \\
\text { (1965) }\end{array}$ & $\begin{array}{l}\text { Decreased viscosity of polystyrene } \\
\text { solution }\end{array}$ & $300 \mathrm{KHz}$ & $20-120 \cdot 10^{3}$ & $0.33 \mathrm{~h}$ & ineversible \\
\hline 3 & $\begin{array}{l}\text { Komar } \\
(1967)\end{array}$ & $100 \%$ paraffin removal & NA & $\overline{\text { NA }}$ & $\begin{array}{l}12.5- \\
23.1 \mathrm{~h}\end{array}$ & $\overline{\mathrm{NA}}$ \\
\hline 4 & $\begin{array}{l}\text { Fairbanks and } \\
\text { Chen } \\
(1971)\end{array}$ & Increased oil percolation rate & $20 \mathrm{KHz}$ & $\begin{array}{l}150 \mathrm{~W} \text { (power of } \\
\text { transducer) }\end{array}$ & NA & $\overline{\text { NA }}$ \\
\hline 5 & $\begin{array}{l}\text { Johnston } \\
\text { (1971) }\end{array}$ & $\begin{array}{l}\text { Decreased viscosity of epoxy } \\
\text { resins, polyamides }\end{array}$ & $\begin{array}{l}47 \text { and } 880 \\
\mathrm{KHz}\end{array}$ & $\begin{array}{l}80 \mathrm{~W} \text { and } 50 \mathrm{~W} \\
\text { (power of } \\
\text { transducers) }\end{array}$ & $\begin{array}{l}30 \mathrm{~s} \\
0.75 \mathrm{~h}\end{array}$ & up $1048 \mathrm{~h}$ \\
\hline$\overline{6}$ & $\begin{array}{c}\text { Abad-Guerta } \\
(1976)\end{array}$ & Removal of paraffin . & NA & $\overline{N A}$ & $0.5-1 \mathrm{~h}$ & $\overline{N A}$ \\
\hline$\overline{7}$ & $\begin{array}{l}\text { Cherskiy et al. } \\
\text { (1977) }\end{array}$ & $\begin{array}{l}\text { Sharp increase in sample } \\
\text { permeability to water }\end{array}$ & $26.5 \mathrm{KHz}$ & $2-9 \cdot 10^{2}$ & NA & several minutes \\
\hline 8 & $\begin{array}{l}\text { Gadier } \\
\text { (1977) }\end{array}$ & $\begin{array}{l}\text { Increased efficiency of oil } \\
\text { displacement by water; decreased } \\
\text { surface tension of transformer oil; } \\
\text { decreased viscosity of } \\
\text { polyacrylamide solution }\end{array}$ & $\begin{array}{c}30 \mathrm{~Hz}-15 \\
\mathrm{KHz}\end{array}$ & $\begin{array}{c}10-40 \mathrm{~W} \\
\text { (power of transducer) }\end{array}$ & T.5h. & $\overline{N A}$ \\
\hline 9 & $\begin{array}{l}\text { Neretin and Yudin } \\
\text { (1981) }\end{array}$ & $\begin{array}{l}\text { Increased rate of oil displacement } \\
\text { by water }\end{array}$ & $\begin{array}{l}50 \cdot 80 \\
\mathrm{KHz}\end{array}$ & $0.8-1.2 * 10^{3} \mathrm{~W} / \mathrm{m}^{2}$ & $\mathrm{NA}$ & $\overline{\mathrm{NA}}$ \\
\hline 10 & $\begin{array}{l}\text { Sokolov and } \\
\text { Simkin } \\
(1981)\end{array}$ & Decreased oil viscosity & $18 \mathrm{KHz}$ & $8 * 103 \mathrm{~W} / \mathrm{m}^{2}$ & $0.5 \cdot 1.0 \mathrm{~h}$ & $120 \mathrm{~h}$ \\
\hline$\Pi$ & $\begin{array}{l}\text { Snarksiy } \\
\text { (1982) }\end{array}$ & $\begin{array}{l}\text { Increased rate of oil displacement } \\
\text { by water }\end{array}$ & $9.40 \mathrm{~Hz}$ & $2 * 10^{3} \mathrm{~W} / \mathrm{m}^{2}$ & $\overline{N A}$ & $\overline{N A}$ \\
\hline 12 & $\begin{array}{l}\text { Medlin et al. } \\
\text { (1983) }\end{array}$ & $\begin{array}{l}\text { Increased rate of oil displacement } \\
\text { by water }\end{array}$ & $100 \mathrm{~Hz}$ & $10^{+} \mathrm{W} / \mathrm{m}^{2}$ & $20 \mathrm{~h}$ & $\overline{N A}$ \\
\hline 13 & $\begin{array}{l}\text { Ashiepkov } \\
\text { (1989) }\end{array}$ & $\begin{array}{l}\text { Increased oil percolation rate } \\
\text { through sample }\end{array}$ & $\begin{array}{c}30-400 \\
\mathrm{~Hz}\end{array}$ & $10^{-2}-10^{3} \mathrm{~W} / \mathrm{m}^{2}$ & NA & $\overline{N A}$ \\
\hline 14 & $\begin{array}{l}\text { Dyblenko et al. } \\
\text { (1989) }\end{array}$ & $\begin{array}{l}\text { Increased rate of kerosene } \\
\text { displacement by water }\end{array}$ & $200 \mathrm{~Hz}$ & $88 \mathrm{~W} / \mathrm{m}^{2}$ & NA & NA \\
\hline 15 & $\begin{array}{l}\text { Pogosyan et al. } \\
\text { (1989) }\end{array}$ & $\begin{array}{l}\text { Accelerated gravitational } \\
\text { separation of kerosene and water }\end{array}$ & $120 \mathrm{KHz}$ & $10^{-1} \mathrm{~W} / \mathrm{m}^{2}$ & $2 h$ & NA \\
\hline 16 & $\begin{array}{l}\text { Kuznetsov and } \\
\text { Simkin (1990) }\end{array}$ & Increased oil mobility & $1.2 \mathrm{~Hz}$ & $10^{5} \mathrm{~W} / \mathrm{m}^{2}$ & $48 \mathrm{~h}$ & $\overline{N A}$ \\
\hline 17 & $\begin{array}{l}\text { Simkin et al. } \\
(1991)\end{array}$ & $\begin{array}{l}\text { Increased rate of kerosene } \\
\text { displacement by water }\end{array}$ & $\overline{N A}$ & $\begin{array}{l}7.8 \mathrm{~m} / \mathrm{s}^{2} \\
\text { (paricle acceleration } \\
\text { in sonic field) }\end{array}$ & $51.92 \mathrm{~h}$ & $\overline{N A}$ \\
\hline 18 & $\begin{array}{l}\text { Simkin and } \\
\text { Surguchev } \\
\text { (1991) }\end{array}$ & Coalescence of oil droplets & $\overline{N A}$ & $\overline{\mathrm{NA}}$ & $2 \min$. & $\overline{\mathrm{NA}}$ \\
\hline 19 & $\begin{array}{c}\text { Cleveland and } \\
\text { Garg } \\
\text { (1993) }\end{array}$ & $\begin{array}{l}\text { Slight increase in contaminant } \\
\text { recovery rate }\end{array}$ & Ultrasonic & $\overline{N A}$ & NA & $\overline{N A}$ \\
\hline 20 & $\begin{array}{c}\text { Reddi et al. } \\
(1993)\end{array}$ & Increase in hydraulic conductivity & $20 \mathrm{KHz}$ & $500 \mathrm{~W}$ & $\begin{array}{l}8 \cdot 10 \\
\min .\end{array}$ & $\overline{N A}$ \\
\hline 21 & $\begin{array}{c}\text { Venkitaraman } \\
\text { (1994) }\end{array}$ & $\begin{array}{l}\text { Increase in permeability in mud } \\
\text { damaged cores }\end{array}$ & $\begin{array}{l}20 \cdot 80 \\
\mathrm{KHZ}\end{array}$ & $20-50 \mathrm{~W} / \mathrm{m}^{2}$ & $\overline{\mathrm{NA}}$ & $\overline{\mathrm{NA}}$ \\
\hline 22 & $\begin{array}{l}\text { Reddi and Challa } \\
(1994)\end{array}$ & $\begin{array}{l}\text { Mobilization of NAPL ganglia } \\
\text { trapped in pore spaces in sand }\end{array}$ & $60 \mathrm{~Hz}$ & NA & $\begin{array}{l}15-20 \\
\min .\end{array}$ & $\overline{\mathrm{NA}}$ \\
\hline
\end{tabular}

NA $=$ Not Applicable or Not Available 
by vibrating a plexiglass tube filled with sand and measuring the flow rates for air and water. The results show that without acoustic excitation the flow through the sand is simple and roughly proportional to the pressure drop across the sample. In contrast, the flow rate changes markedly when the sample is subjected to an AEF with an increase in permeability on the order of 30 percent.

Reddi and Challa (1994) conducted laboratory experiments to investigate how vibrations can mobilize non-aqueous phase liquid (NAPL) ganglia in sands. Their experiments were conducted using a shaking table operating at a single frequency of $60 \mathrm{Hertz}$ and with no confining pressure on the sediment. Their results indicate that vibrations in a fluid-saturated porous medium, when augmented by suitable flow conditions, can effectively mobilize and extract NAPL ganglia from sands.

\section{PROJECT DESCRIPTION}

\section{The Team}

Weiss Associates (WA) has been contracted by the United States Department of Energy, Morgantown Energy Technology Center under Contract No. DE-AR21-94MC30360 to develop a new technology involving the use of acoustic energy to enhance the remediation of contaminated soil and ground water. This work referred to as the DOE Acoustic Remediation Program will be conducted by a team comprised primarily of personnel from WA and Scientific Applications and Research Associates (SARA), Inc. located in Huntington Beach, California.

WA is an environmental engineering and hydrogeological service company with over 14 years of experience in subsurface characterization and remediation. WA personnel are highly skilled and experienced in the areas of regulatory compliance and permitting, site characterization, air quality, ground water modeling, risk assessments, and remediating subsurface contaminants in soil and ground water. WA fully serves seven of the thirty-one Federal Superfund sites in the San Francisco Bay Area. WA is the developer of the concept of using an AEF to enhance the subsurface remediation of contaminants in low-permeability soils and bedrock.

SARA, Inc. is a technology development company with extensive experience conducting research in acoustic technology for military and commercial applications. SARA, Inc. personnel have an extensive background in applied physics and electrical engineering, experimental and theoretical investigations of non-linear processes in materials, signal processing and control, and the development of high power acoustical sources.

Additional team members are Ms. Dorothy Bishop and Mr. Brian Bonner at Lawrence Livermore National Laboratory and Dr. James $\mathbf{K}$. Mitchell of the Department of Civil Engineering at the Virginia Polytechnic Institute. Dr. Mitchell is a member of the National Academy of Engineering and an internationally recognized authority on soil behavior and soil mechanics.

\section{The Project}

The remediation of fine-grained soils is a slow process because of their low permeability and generally high absorptive capacity. The DOE Acoustic Remediation Program will investigate the use of an acoustic excitation field (AEF) to enhance the rates of fluid and contaminant extraction from these sediments. One concept of how the subject technology may be utilized in the subsurface is shown in Figure 1. In this example, we use a borehole/well with downhole acoustic 
sources to generate and propagate the AEF. An extraction well recovers the fluid and contaminant by pumping it to the surface where it is subsequently treated and/or disposed.

The overall program has three phases. The initiation of each new phase is dependent upon the successful completion of the previous phase.

- Phase I - Laboratory Scale Parametric Investigation

- Phase II - Technology Scaling Study

- Phase III - Field Demonstration systematically evaluate the relationships between the fluid and contaminant extraction rates, the frequency and power density of the $A E F$, and induced physico-chemical changes for a variety of soil types at different pressures and saturation conditions.

Phase II is a technology scaling study conducted to (1) verify Phase I results at a larger scale on the order of 1,000 gallons, (2) evaluate the technical performance, safety and cost of acoustically enhanced remediation; (3) develop an optimal field design, and (4) validate a numerical model of the acoustically enhanced remediation process at the scale of the Phase II testing.

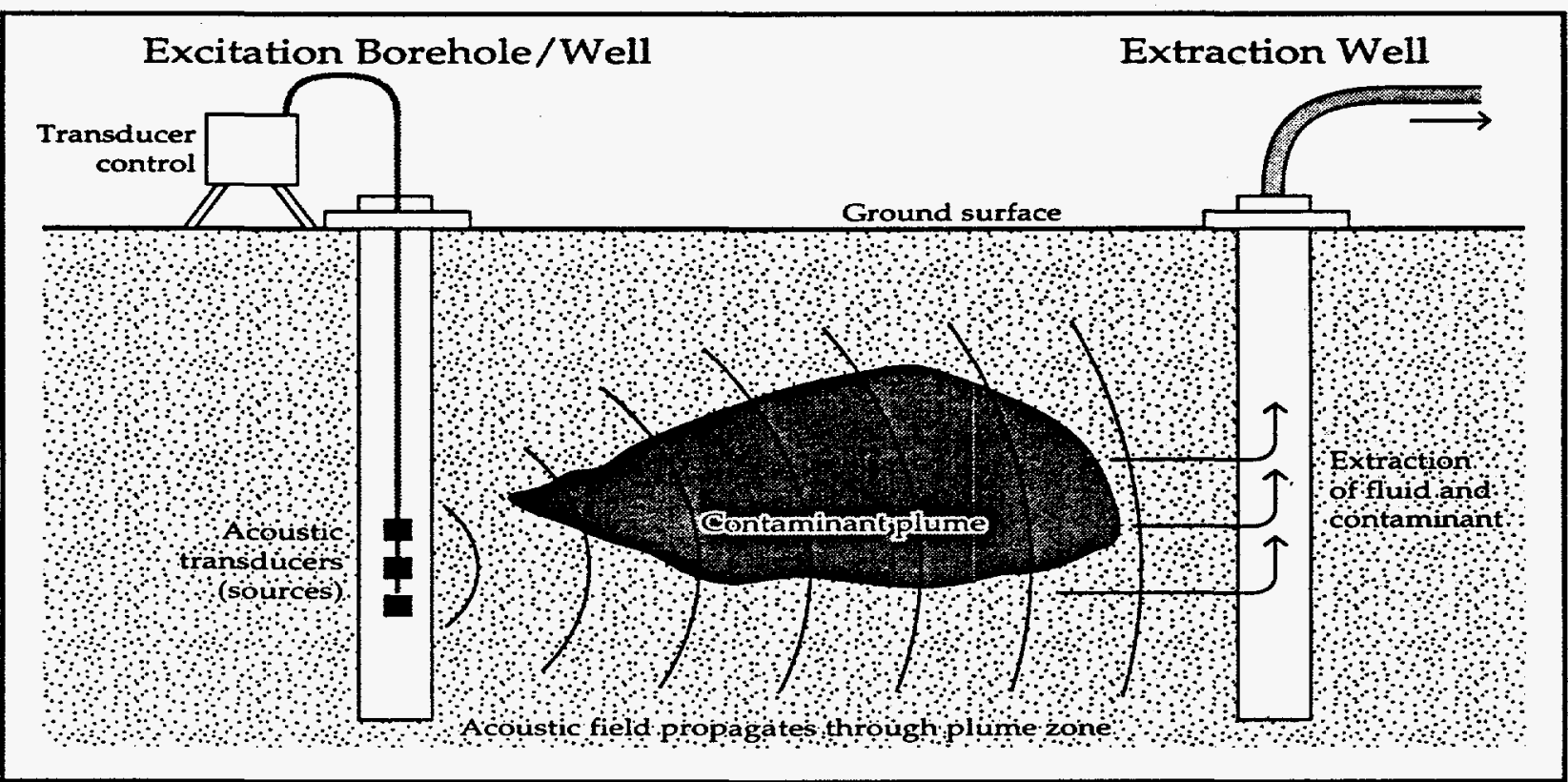

Figure 1. The Acoustically Enhanced Remediation Concept

Phase I consists of a series of laboratory experiments designed to (1) verify that AEF technology can enhance the in-situ remediation of contaminated soil and ground water, and (2)
Phase III consists of two parts. Part 1 will be conducted at a non-industrialized, clean test site to (1) verify that acoustically enhanced remediation can be operated in the field safely and predictably, 
(2) evaluate various acoustic sources and control techniques, (3) evaluate the field deployment methodology prior to contaminated site application, and (4) validate a numerical model of the acoustically enhanced remediation process at a field scale. Part 2 will be conducted at an industrialized, contaminated site to verify that acoustically enhanced remediation (1) can significantly enhance contaminant recovery from soil and ground water, and (2) is safe and economical.

\section{Phase I Laboratory Scale Investigation}

Figures 2 and 3 (following pages) summarize the potential effects of acoustic excitation on the porous grain framework of the soil and the pore fluids, respectively. While there have been many observations to indicate the potential of acoustically enhanced soil and ground water remediation, many of the previous data consist of single point measurements. The Phase I effort will provide a laboratory-scale proof of concept and fully characterize the effects of AEFs on fluid and contaminant extraction rates. In addition, we will conduct a Technology Merit and Trade Study. The tasks in Phase I are shown in the contract information.

A key question, to be addressed in Phase I, is whether there are beneficial effects of AEFs at low power densities and strain levels, or if high power densities are required to drive the soil at strain amplitudes where the material response is non-linear. If there are beneficial effects at low power densities, then the eventual field design can probably be comparatively simple (and less expensive) with a relatively small number of acoustic sources. If higher power densities are required, our engineering analyses (described in the next section) show that high power densities can be accomplished using source arrays with advanced control techniques. The laboratory experiments in Phase I will cover nearly the entire range of frequencies and power densities of potential interest.

We will analyze the influence of AEFs in laboratory-size, unconsolidated soil samples. Our objective is to understand the physical effects of AEFs on contaminated soil and ground water through a series of well-controlled experiments and to evaluate estimates of the soil transport properties and process parameters. These data will be used in a computer model of the enhanced soil remediation process. This model will allow (1) an initial quantitative estimate of the efficiency and effectiveness of acousticallyenhanced soil and ground water remediation, (2) design and planning of Phase II which will address technology scaling from the laboratory to the field, and (3) predictions of how acousticallyenhanced remediation will work under field conditions.

We are taking this approach, rather than trying to simulate the remediation process in a laboratory-size sample, because the acoustic wavelengths are much longer than the sample size and it is physically impossible to simulate the field geometry in a laboratory sample. Therefore, the only possible approach is to measure the basic material properties in laboratory-size samples, incorporate the results in a computer model of the remediation process, and then to validate the computer model during Phase II tests at a larger scale on the order of 1,000 gallons.

\section{RESULTS}

Work under this contract was initiated on July 21,1994 . At this time, we are in the process of completing our literature review, finalizing the Detailed Test Plan, assembling the laboratory test apparatus and beginning a Technology Merit and Trade Study. 
(1)

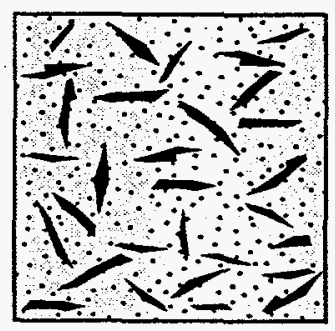

(2)

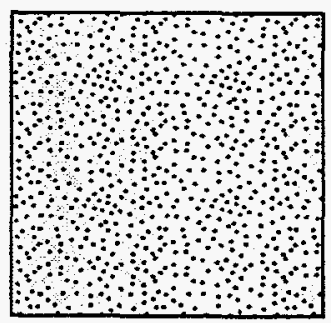

(3)

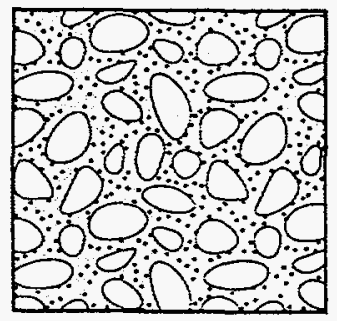

(4)

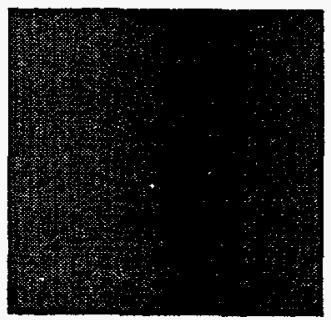

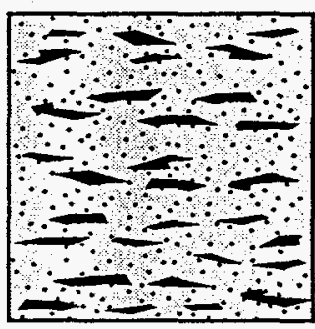

Flow Direction
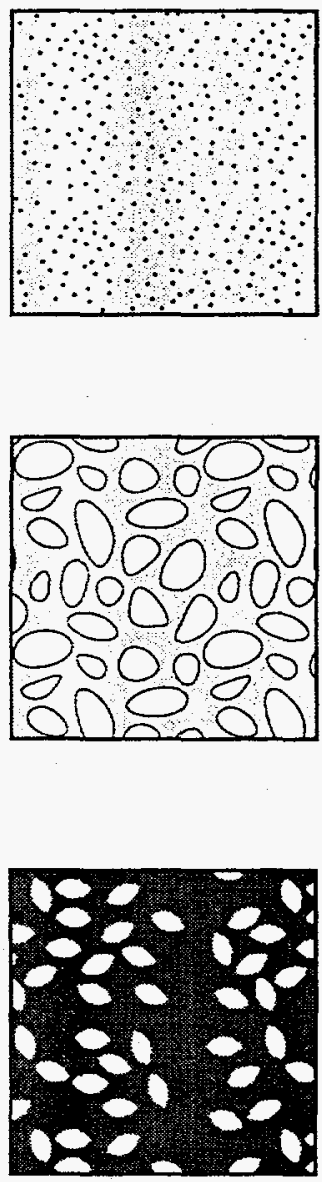

Vibrational alignment or reordering of material to change impedance in flow direction.

Temporary increase in porosity due to particle agitation.

Disintegration of organic or aggregate material blocking pore.

Cavitation (openings, bubbles) produced in clay/silt to increase porosity and permeability.

Figure 2. Potential Effects of Acoustic Excitation on Porous Grain Framework 

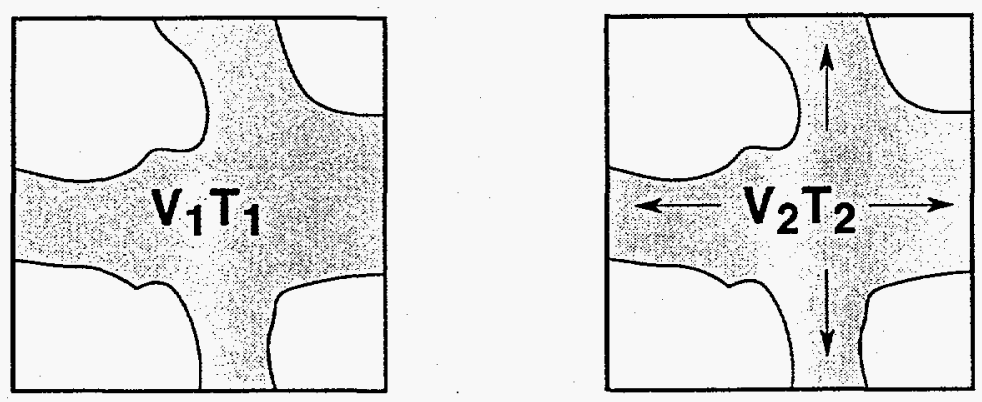

Increase in kinetic energy increases temperature ( $T$ ) volume (V), and pore pressure (arrows).
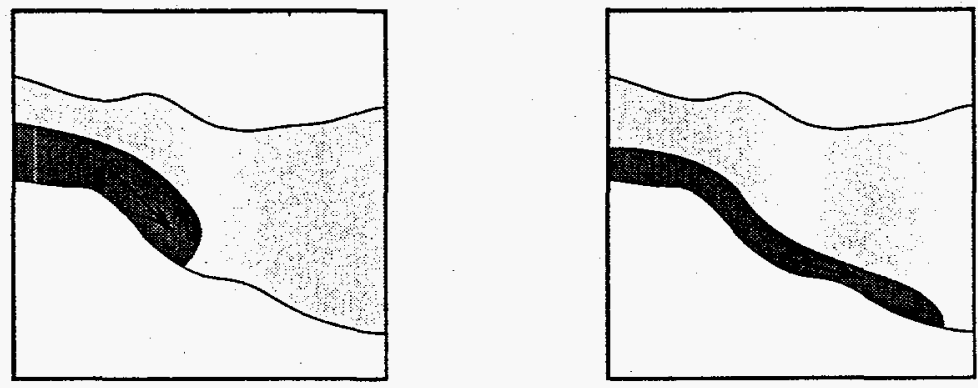

Decrease in viscosity of fluid phases increases flow rate.

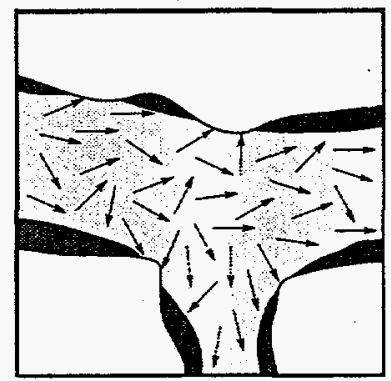

Increase in molecular movement causes disintegration and mobilization of sorbed contaminants.

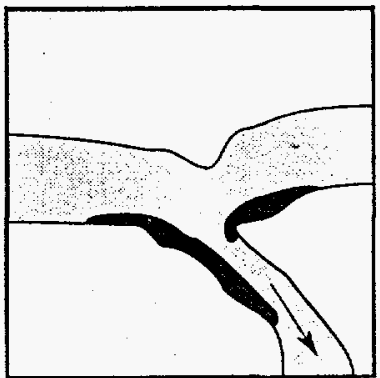

Lower surface tension will allow stationary droplets to coalesce and flow.

Figure 3. Potential Effects of Acoustic Excitation on Pore Fluids, 


\section{Literature Review}

Keyword searches have been performed on several major data bases including the National Technology Information Service, Searchable Physics Information Note, U.S. Army Engineer Waterways Experiment Station Database, Earth Science Data Center, Compendix, Alternative Treatment Technology Information Center, Cleanup Information Bulletin Board System, Gopher Internet Searches, and the University of California text and periodical catalogs.

Abstracts for over 200 relevant papers were identified during this process. After review of the abstracts, relevant papers were acquired and a brief summary was entered into a tabular database. Selected abstracts discuss relevant laboratory data, instrumentation and sources, theory, similar processes or other directly pertinent information. Selected papers from the former Soviet Union, published in Russian, are being translated and will be added to this database.
An on-line patent search was performed through Shadow Patents, Inc., and over 50 related patents were identified. Most of these patents were issued to a sole individual Mr. Albert Bodine, and none of them appear to conflict the with DOE Acoustic Remediation Program.

\section{Detailed Test Plan}

Table 2 summarizes the different experiments that will be conducted for each of the four soil types. During each experiment, baseline measurements will first be made without acoustic excitation. Measurements will then be made during acoustic excitation at a series of at least three frequencies between 50 and 2,000 Hertz and at three power levels up to $10^{5}$ Watts/meter ${ }^{2}$. Tests will generally be run at confining pressures between 10 and 100 psi which will simulate the stress conditions in the near-surface and a 100 feet (30 meters) below the ground surface.

The experiments will be conducted to provide information on soil hysteresis effects and how

Table 2. Test Series Summary - Phase I Laboratory Scale Parametric Investigation

\begin{tabular}{|c|c|c|c|c|}
\hline Soil Type & $\begin{array}{c}\text { Single Phase } \\
\text { Permeability } \\
\text { Purging with } \\
\text { Water }\end{array}$ & $\begin{array}{c}\text { Single Phase } \\
\text { Permeability } \\
\text { Purging with Air }\end{array}$ & $\begin{array}{c}\text { NAPL } \\
\text { Extraction } \\
\text { Purging with } \\
\text { Water }\end{array}$ & $\begin{array}{c}\text { NAPL Extraction } \\
\text { Purging with Air }\end{array}$ \\
\hline Fine Sand & $\checkmark$ & $\checkmark$ & $\checkmark$ & $\checkmark$ \\
\hline Silt & $\checkmark$ & & & \\
\hline Clay & $\checkmark$ & & $\checkmark$ & $\checkmark$ \\
\hline Plasticine Clay & $\checkmark$ & $\checkmark$ & $\checkmark$ & \\
\hline $\begin{array}{c}\text { Lawrence } \\
\text { Livermore } \\
\text { National } \\
\text { Laboratory Soil }\end{array}$ & $\checkmark$ & & & \\
\hline
\end{tabular}


long the effects of acoustic excitation persist in a particular soil. The test program is designed so that an early parametric study will enable us to pursue encouraging trends in the data. Thus, we will determine the optimal acoustic parameters to maximize the fluid and contaminant extraction rates for a wide range of soil types under both saturated and unsaturated conditions.

The single-phase measurements of hydraulic and air conductivity will be repeated three times, except for the clay sample, to verify that the results are statistically significant and not simply due to sample variability. We expect that we will be able to prepare nearly identical samples of each soil material. While there will be inevitably some variability among samples, in our data analyses, we will focus on the relative changes in fluid and contaminant extraction rates with and without acoustic excitation.

Due to the time-consuming nature of the analyses, we will follow simplified procedures, using only selected frequencies and power levels, to evaluate how acoustic excitation affects the hydraulic conductivity of clay, and the rates of NAPL ground water and soil vapor extraction. If we find an increased flow and/or contaminant extraction rate with acoustic excitation, then we will go back and endeavor to identify the optimal acoustic parameters for remediation.

\section{Laboratory Test Equipment}

Figure 4 (next page) shows a schematic of the Phase I laboratory test apparatus. This apparatus uses an electromechanical shaker to excite vibrations in a test sample of unconsolidated soil approximately 1.5 " diameter and 4 " long. As the test sample and top end cap are accelerated by the shaker, the inertial loading of the test sample due to it own mass and the mass of the top end cap generates a relatively uniform strain field in the test sample. We conducted a series of engineering analyses to verify the suitability of this approach. The results of these analyses predict that we can expect to achieve power levels over $10^{5}$ Watts/meter ${ }^{2}$ and strain amplitudes in the test sample above $10^{-4}$ at frequencies between 50 and 5,000 Hertz.

The soil sample is jacketed between two end caps which are fitted with porous metal filters for permeability measurements. The shaker and sample assembly are enclosed in a sealed chamber that is pressurized to simulate the stress on a soils at different depths in the subsurface.

The soil sample will be instrumented with three different types of sensors.

- A dynamic pressure transducer will be placed in direct contact with the soil material at each end of the test sample to directly measure the applied stress in the sample. With these stress measurements and an estimate of Young's modulus calculated from the resonant frequency of the sample, we will be able to evaluate the strain amplitude, or fractional change in length, of the soil sample.

- A small accelerometer will be mounted in each of the end caps to measure the vibrations (that is the acceleration, velocity and displacement) at the top and bottom of the sample. These sensors will be used to verify that the sample is being excited in a uniform manner by the shaker.

- Temperature measurements will be made using three thermocouples equally spaced along the length of the sample.

The pressure drop across the sample will be directly measured using a differential pressure transducer. The driving pressure on the purging 
agent reservoir and the confining pressure will also be measured and recorded.

\section{Technology Merit and Trade Study}

As described above, a key question to be answered by the laboratory-scale analyses is whether there are beneficial effects of AEFs at low power densities and strain levels, as
- Looking ahead, we completed an initial acoustic trade study to evaluate the range of frequencies and power levels that are achievable in the field, in case it turns out that we need to drive the soil at higher power levels. This trade study provides useful bounds or constraints on the range of frequencies and power densities that can reasonably be achieved using focused source arrays and advanced control techniques.

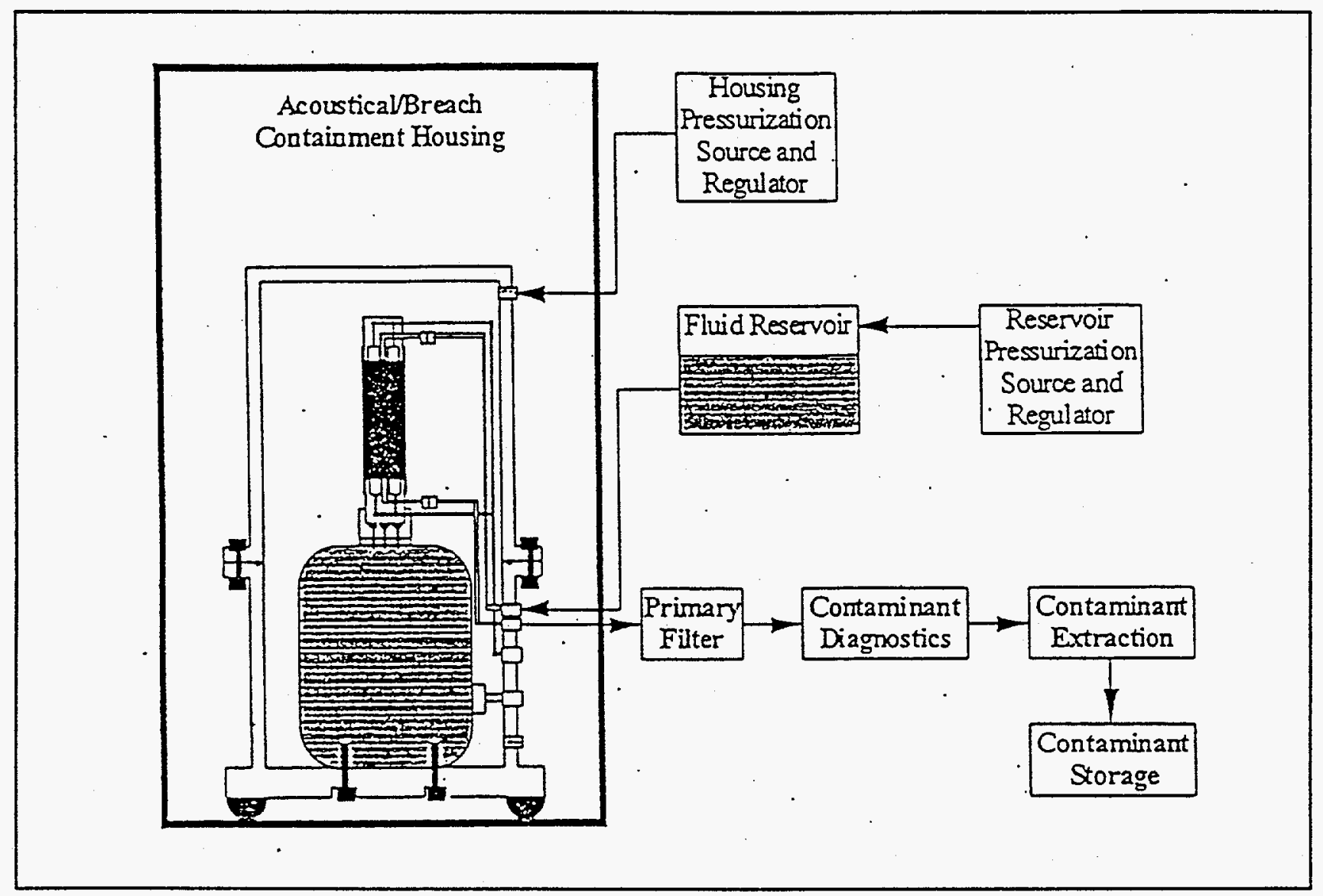

Figure 4. Layout of Laboratory Test Equipment - Phase I Laboratory Scale Parametric Investigation

suggested by the oil field studies from the former Soviet Union, if high power densities are required to drive the soil at strain amplitudes where the material response is non-linear.
The results of this initial acoustic trade study are summarized graphically in Figure 5 (next page). First, there is an upper bound on the range of possible frequencies near $30 \mathrm{kHz}$. At higher frequencies, strong acoustic attenuation in 
the sediments will severely limit the possible remediation volume. The lower frequency limit is determined by the available acoustic power and by the fact that at low frequencies it will be difficult to focus the acoustic energy into a compact remediation volume. Multiple factors, including non-linearities, acoustic scattering and heterogeneities in the subsurface velocity field, will contribute to a practical upper bound on the acoustic intensity. region, which may extend to lower strain amplitudes, where it should be possible to conduct acoustically enhanced remediation. The laboratory experiments in Phase I will cover nearly the entire range of frequencies and power densities of potential interest.

\section{FUTURE WORK}

Our primary activities during the next six

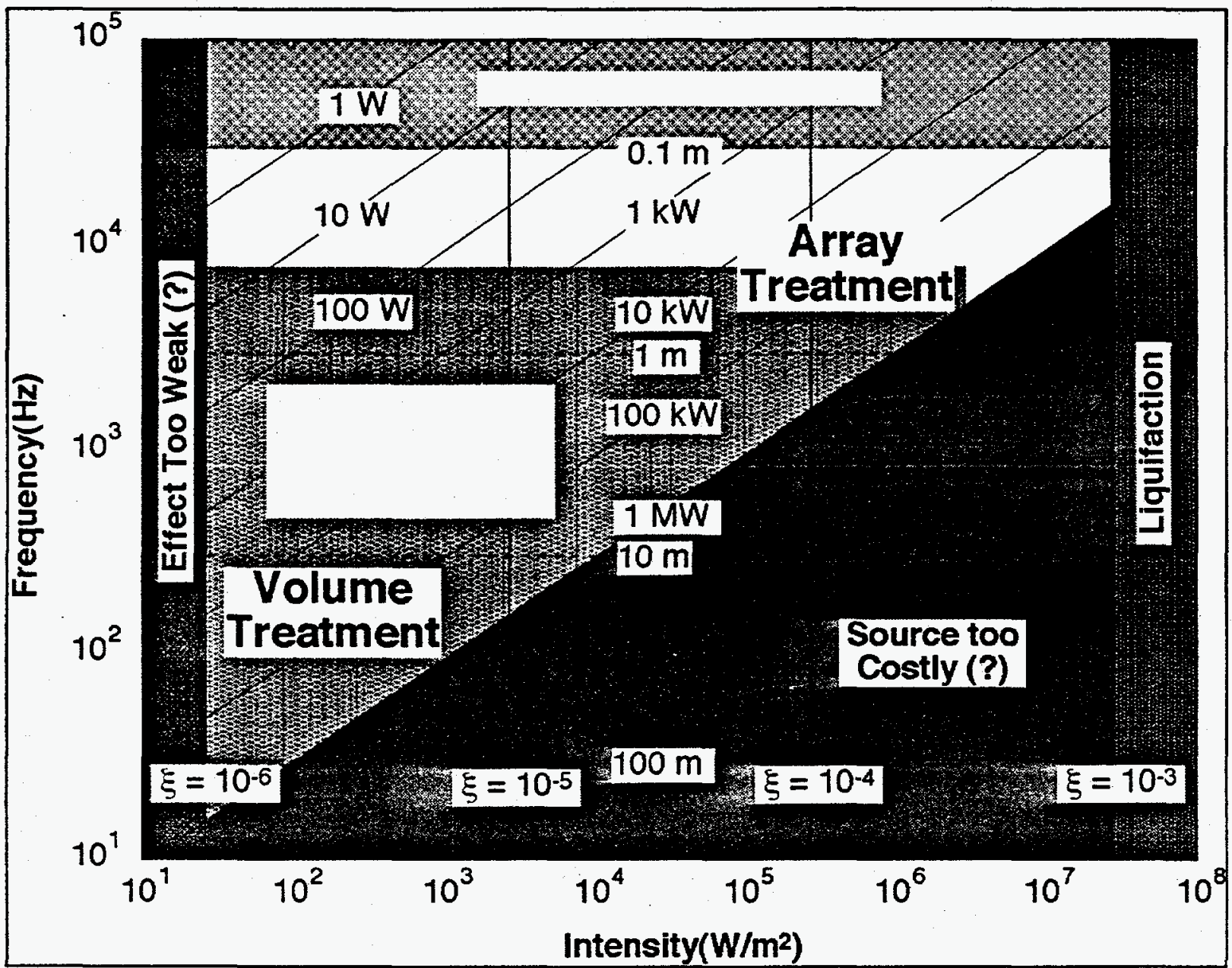

Figure 5. Acoustic Trade Study Shows Region Where Acoustically Enhanced Remediation Should be Possible.

Taken together, the frequency limits and the upper bound on the acoustic intensity define a months will involve (1) finalizing the Detailed Test Plan, (2) final assembly and shakedown 
testing of the laboratory test apparatus, (3) completion of the laboratory test program, and (4) data analysis. While the laboratory test apparatus is being assembled and tested, there will be parallel development of the laboratory data acquisition system and data reduction tools.

\section{REFERENCES}

Beresnev, I. A. and Johnson, P. A., 1994, Elasticwave stimulation of oil production: a review of methods and results, Geophysics, v. 59, n. 6, pp. 1000-1017.

Duhon, R., 1964, An investigation of the effect of ultrasonic energy on the flow of fluids in porous media: Ph.D. thesis, The University of Oklahoma.

Reddi, L. N. and Challa, S., 1994, Vibratory mobilization of immiscible liquid ganglia in sands, Journal of Environmental Engineering, v. 120 , n. 5, pp. 1170-1190.

Weiss Associates, 1993, Acoustically enhanced remediation of contaminated soils and ground water: Research Opportunity Announcement proposal submitted to Morgantown Energy Technology Center in response to Solicitation No. DE-RO21-93MC30140. 